\title{
Coastline Changes On The Coast of Cirebon Using Landsat
}

\author{
Khadijah, Ratna Saraswati , Adi Wibowo \\ Department of Geography, Faculty of Mathematics and Natural Science, University of Indonesia, \\ Depok - Indonesia
}

\begin{abstract}
The coastal region is a very dynamic region because it undergoes two processes, natural and non-natural. The coastline can change due to waves, tides and human activities. Human activities are mostly carried out in coastal areas including reclamation for ports. Coastal area of Cirebon is one of the areas that experiences land addition or port reclamation which causes changes in the coastline. Images interpretation is one way to find out changes that occur in coastal areas by using Landsat 8 OLI and Landsat 5TM imagery. The image extraction method using RGB 432 can see the differences between the sea-land and how the changes has occurred in the last ten years, by overlaying both of them which results in extensive abrasion and accretion that occurs on the coast of Cirebon. The abrasion area is $107.12 \mathrm{Ha}$ and the accretion is $941.17 \mathrm{Ha}$.
\end{abstract}

\section{Introduction}

The coastal area is a very dynamic region due to the existence of two natural processes which are the deposition of material carried by rivers to the estuary and abrasion of sea water waves [1]. The processes caused a change in the coastline which produces the addition and reduction of coastal land. Coastline changes caused by natural processes and non-natural. Natural processes such as hydro-oceanographic processes occurring in the sea due to the pounding waves, changes in flow patterns, and the tidal variation [2]. While nonnatural process caused by human activities also land conversion decision of coastal protection and development of coastal areas that are not in accordance with the applicable rules and causing imbalances sediment transport along the coastline [3].

The coastline generally changes over time in line with natural changes such as wave activity, wind, tides and currents, and river delta sedimentation. Changes in the coastline also occur due to disruption of coastal ecosystems such as the construction of embankments and canals, also buildings around the coast [4]. Various human activities in the coastal area can cause changes in the structure of the beach from natural conditions, both naturally occurring such as siltation and erosion or artificial activities such as coastal reclamation [5]. Coastal reclamation or the addition of a coastline can be beneficial because new land arises, while on the other side causes new problems in the coastal area [6]. Government activities in the city of Cirebon will reclaim the coast to build a pier and housing in the middle of the sea. Coastal reclamation can create a changes in the ecosystem around the reclaimed area.

\footnotetext{
*Corresponding author: ratna.saraswati@ui.ac.id
} 
Some changes that may occur are in the form of changes in current patterns, erosion and sedimentation [7]. Based on explanation above, the aim of this study is to find out the extent of abrasion and accretion over the past 10 years on the coastline of Cirebon coast.

\section{Materials and Methods}

\subsection{Study Area}

The research was conducted in the coast area of Cirebon. Based on geographical location, Cirebon Regency is in West Java Province, which is located on the island of java between $108 \mathrm{o} \mathrm{40'}$ 'and 1080 48' South latitude and between 6o30' and 7o 00' East longitude. The land area extends from the Northwest to the Southeast. Based on the ground level, it can be divided into two parts that is lowland and highland area. Cirebon Regency has an area of $990.36 \mathrm{~km}^{2}$ with an altitude from sea level as high as $0-130$ meters.

\subsection{Materials}

Using image data with Landsat 8 OLI and Landsat 5 TM imagery on path 121 row 65, respectively recorded in November $7^{\text {th }} 2019$ and June 2009 with RGB 543 to differential between sea and land. The base map used sea map with scale 1:100,000 coastline areas of Cirebon (Fig1).
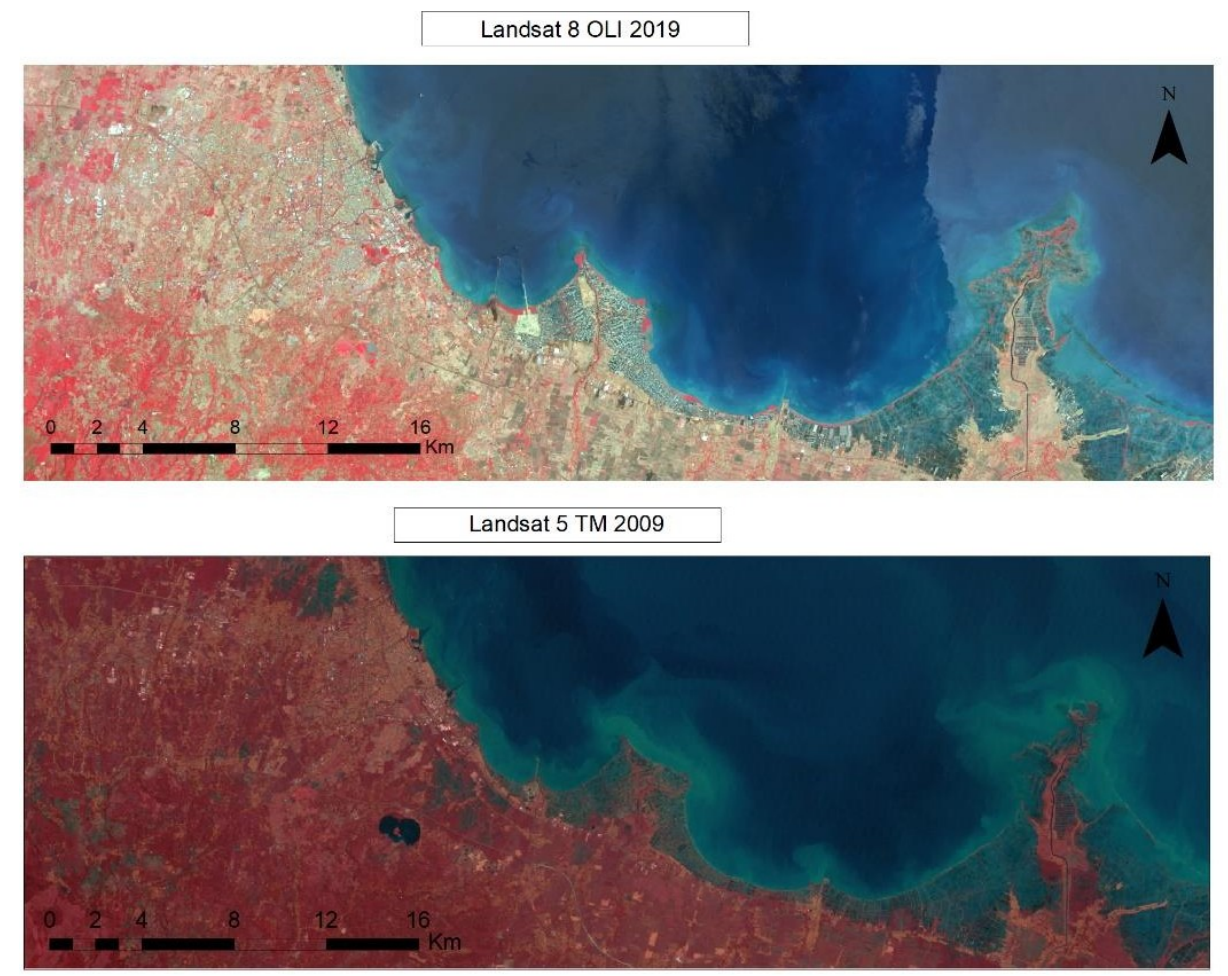

Fig. 1. Study Area in Coastline of Cirebon using Landsat Imagery 


\subsection{Methods}

Coastline extraction method can be obtained simply by extracting a single band, because the reflectance of the water column which is approximately equal to zero from the infrared band. Previous research showed that the infrared band can extract the land-sea interface [8].

Determination of the coastline used in research is a visual interpretation of the appearance of objects by using composite 543 (RGB) because the clear boundary between sea water and land can be drawn [9]. Spatial analysis is used to spatially analyze the coastline conditions by looking at patterns based on map processing that has been done. And to find out the factors that most influence on coastline changes on the Cirebon coast. Then the overlay process is carried out between the data in 2009 with 2019 which is then carried out spatially analysis to see the differences that appear. During a visual interpretation attention to the position of coastline, particularly the possibility of the appearance of the land still wet due to the influence of the tides.

\section{Result and Discussion}

The results of coastline extraction were analyzed for 10 years from 2009 to 2019 shows the dynamic conditions of the coastline. The condition of the coastline that are found at one points shows the coastline moving towards the sea, while others show a retreat towards the mainland. The observations also show that the eastern region of coastal sub district Pangenan and Losari, especially in estuaries, underwent significant changes (Fig2).

\section{Accretion and Abrasion in Cirebon}

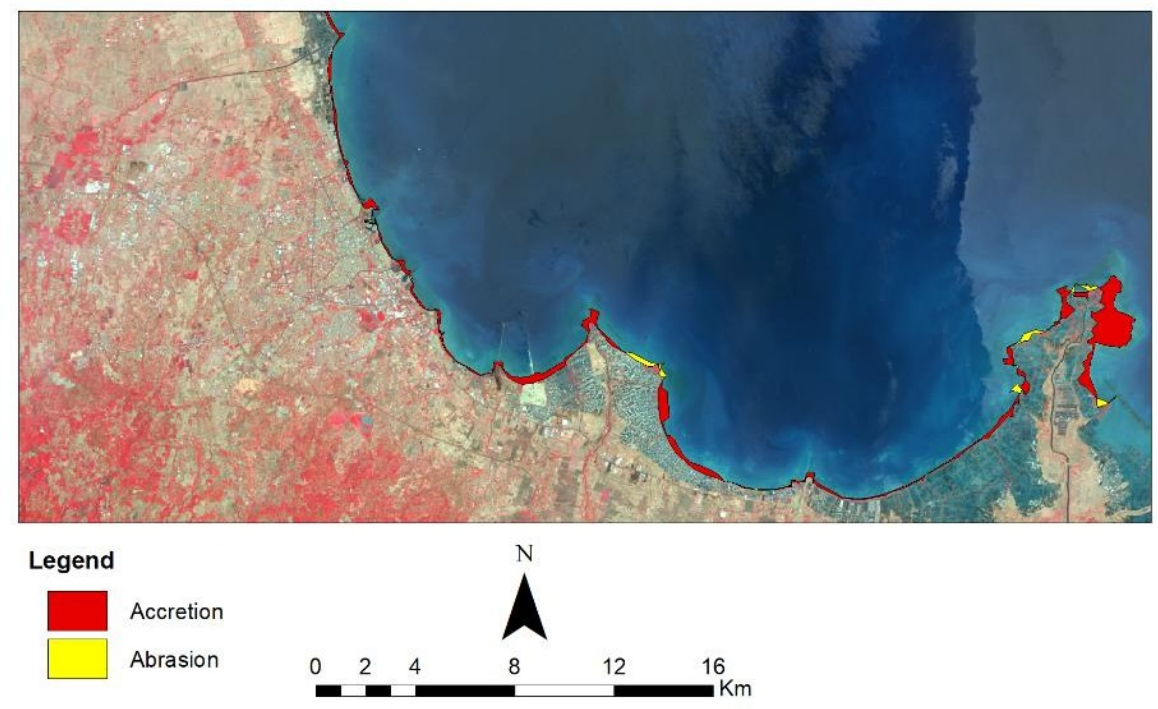

Fig. 2. Results Abrasion and Accretion in Cirebon

The following is the result of data processing for coastline changes on the coast of Cirebon by digitizing and extracting images. It can be seen on the map that accretion occurs on the coast which is significant than the abrasion in the eastern part, showing an accretion area of $941,17 \mathrm{Ha}$ and abrasion area is $107,12 \mathrm{Ha}$. The observations also show that the 
eastern region of coastal sub-district Pangenan and Losari, especially in estuaries, underwent significant changes a lot of abrasion occurred in the Pangenan sub-district.

\section{Eastern of Cirebon}

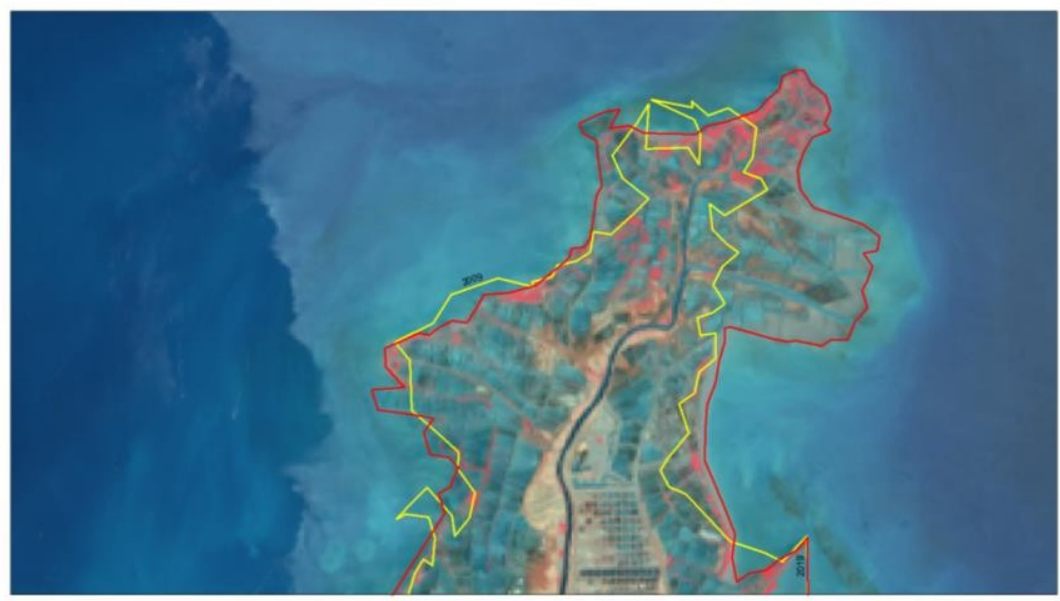

\section{Legend}

2009

2019

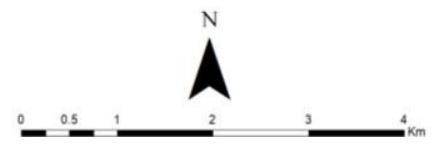

Fig. 3. Results coastline changes in Eastern of Cirebon

\section{Coast in Cirebon City}

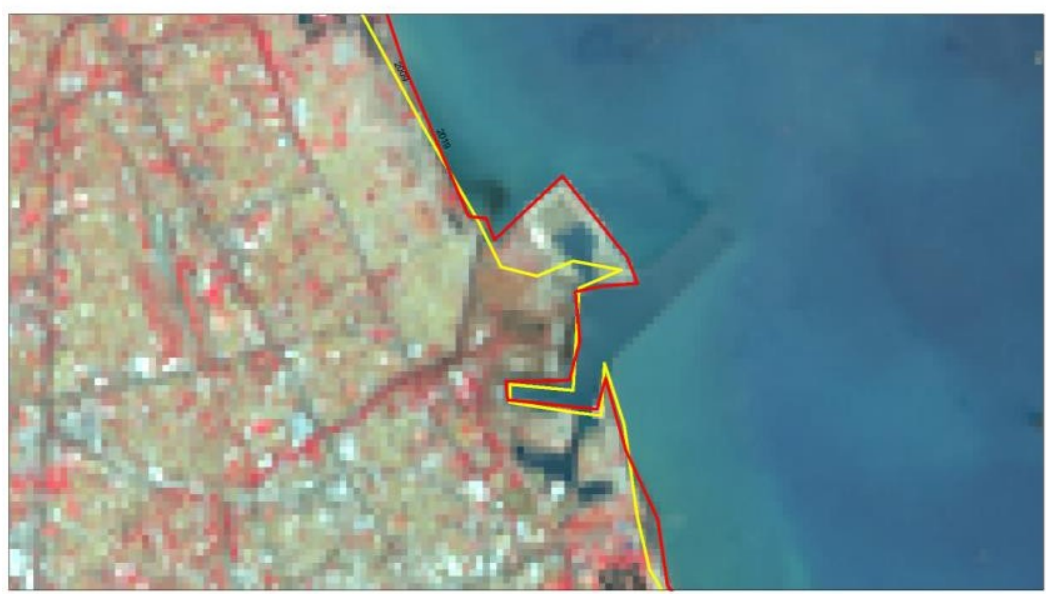

\section{Legend}

2009

2019

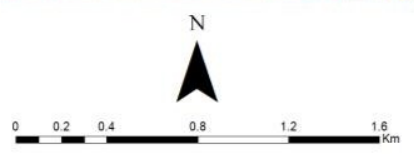

Fig. 4. Results coastline changes in Cirebon City 
Significant coastline changes are in the east, over the past 10 years experiencing land shifts from ocean currents (fig.2). Different from the western part, Cirebon City in the Kejaksaan District has experienced accreasing land due to human activity in the form of port development reclamation by some company. Significant reduction or land abrasion occurred in Pangenan District, Cirebon Regency (fig.3). The overall area of coastline changes in the length of the coast of Cirebon both accretion and abrasion that occurred in the range $2009-2019$. Changes occur due to the process of erosion of land (abrasion) and an increase in land (accretion). This process is caused by sediment transport, tides, waves, currents and human activities [10]. The results of data processing shows the differences after 10 years.

Tidal 2009

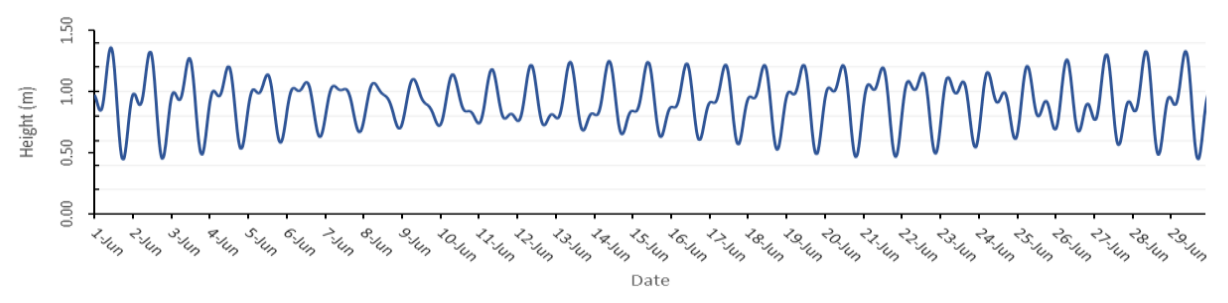

Fig. 5. Tidal Graphic 2019

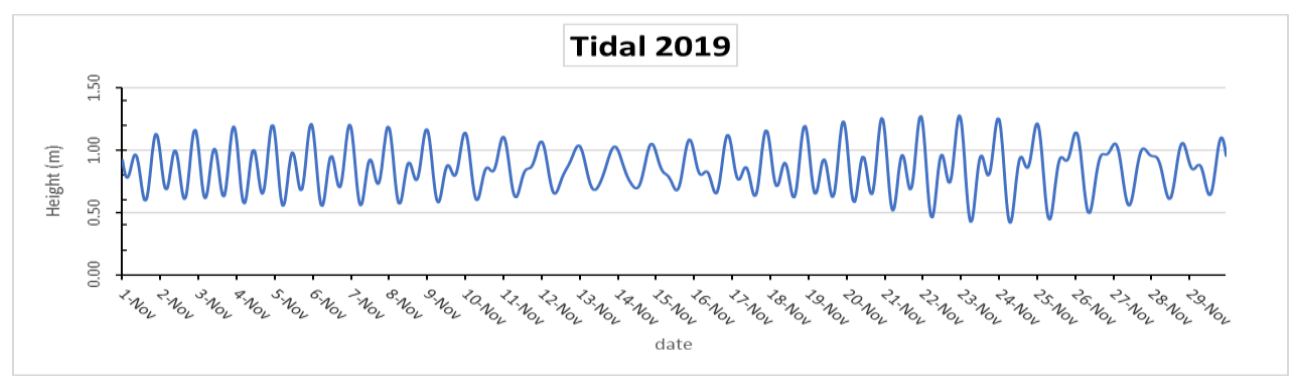

Fig. 6. Tidal Graphic 2009

Graphic of tidal on 2019 and 2009 shows the condition of the image at that time was experiencing ebb (fig 4. 5). This hydrographic mapping has the difference between the coastline and the lowest water line (chart datum) where the coastline is the average position of high water, while the low water line is when water is low, or in the bathymetry map as 0 (low waterline) [11] This line is used as a determinant of maritime boundaries [12].

Tidal data which results in graphs with height and time occurs (fig.4.5). Graph of tidal is using the average sea level, the tide charts for 2009 and 2019 are obtained, which shows the monthly graph. Based on data obtained from the Badan Informasi Geospasial, the tides that occur on the coast with a tide of less than 2 meters. In November 2019 the average tide was 0.86 and in June 2009 it was 0.91 meters. The difference in mean sea level conditions is influenced by currents and waves that cause accretion in the eastern part.

\section{Conclucion}

It can be concluded that the coast of Cirebon underwent a change in the coastline. In the last 10 years the coast of Cirebon experienced abrasion and uneven accretion. Accretion occurred in the eastern part of Cirebon in the Losari sub-district which was quite significant 
and additional land was also carried out in the coastal city of Cirebon, while abrasion occurred in the Kejaksan sub-district. Through spatial data processing by overlay the 2009 and 2019 coastlines, the area of abrasion and accretion is obtained. Abrasion on the coast of Cirebon is $107,12 \mathrm{Ha}$ and the accretion is $941,17 \mathrm{Ha}$. Tides are one of the causes of abrasion and accretion. Tides are very influential on the processed image data obtained. The difference in mean sea level conditions is influenced by currents and waves that cause accretion in the eastern part.

\section{Acknowledgement}

The author would like to thank Directorate of Research and Community Service (DRPM) Universitas Indonesia, which has supported this research in Publikasi Terindeks Internasional (PUTI) Prosiding UI Year 2020 with contract number NKB-1037/UN2.RST/HKP.05.00/2020.

\section{References}

1. K. Munibah, A. Iswati, \& B. Tjahjono. Globe. Perubahan Garis Pantai dan Regulasi Pengelolaan Lahan Baru di Delta Cipunagara, Subang, Jawa Barat., 12(2), 151-159 (2010)

2. Halim, Halili, \& Afu, L. O. A. Sapa Laut. Studi Perubahan Garis Pantai Dengan Pendekatan Penginderaan Jauh Di Wilayah Pesisir Kecamatan Soropia., 1(1), 24-31 (2016)

3. R. Shuhendry. Master Thesis, Diponegoro University Postgraduate Program. Abrasi Pantai Di Wilayah Pesisir Kota Bengkulu: Analisis Faktor Penyebab Dan Konsep Penanggulangannya. (2004)

4. M. Hanafi. Puslitbang Geologi Kelautan. Studi Perubahan Garis Pantai Kaitannya dengan Pengelolaan Wilayah Pesisir Indramayu Jawa Barat (2013)

5. X. Zhang, D. Pan, J. Chen, Q. Zhu, \& H. Huang. Remote Sensing, Evaluation of coastline changes under human intervention using multi-temporal high-resolution images: A case study of the Zhoushan Islands, China. 6(10), 9930-9950 (2014)

6. B. Triatmodjo. Yogyrakarta: FT. TGM. Teknik Pantai. (1999)

7. A. Bambang, K. Sambodho, \& Suntoyo. Studi dampak reklamasi di Kawasan kejeran dengan penekanan pada pola arus dan transport sedimen (2012)

8. A. A. Alesheikh, A. Ghorbanali, \& N. Nouri. Journal environmental Science Technology. Coastline change detection using Remote Sensing. 4(1): 61-66 pp.

9. G. Winarso, Syarif Budhiman \& Judijanto. Proceeding on 22nd Asian Conference on Remote Sensing, CRISP NUS and Asian Association on Remote Sensing, Singapura. The Potential Application of Remote Sensing Data for Coastal Study.(2001)

10. M. Arief, G. Winarso, T. Prayogo. Penginderaan Jauh Journal. Kajian Perubahan Garis Pantai Menggunakan Data Satelit Landsat Di Kabupaten Kendal. 8, 71-80 (2018)

11. G. Winarso, H. Joko, \& S. Arifin. Penginderaan Jauh Journal. Kajian Penggunaan Data Inderaja Untuk Pemetaan Garis Pantai (Studi Kasus Pantai Utara Jakarta). 6, 65-72 (2009)

12. Republik Indonesia. Lembaran Negara RI tahun 1999 No. 3839. Sekretariat Negara, Jakarta. Undang-undang No 22 Tahun 1999 tentang Pemerintah Daerah. (1999) 